\title{
Potato Late-Blight Management in the Toluca Valley: Forecasts and Resistant Cultivars
}

\author{
Niklaus J. Grünwald, Cornell-Eastern Europe-Mexico (CEEM) Potato Late Blight Project, c/o PICTIPAPA, Con- \\ junto Sedagro, Metepec, Edo. de México 52142, México and Department of Plant Pathology, Cornell University, \\ Ithaca, NY 14853; Oswaldo A. Rubio-Covarrubias, Instituto Nacional de Investigaciones Forestales, Agrícolas y \\ Pecuarias (INIFAP), Conjunto Sedagro, Metepec, Edo. de México 52142, México; and William E. Fry, Department \\ of Plant Pathology, Cornell University
}

\begin{abstract}
Grünwald, N. J., Rubio-Covarrubias, O. A., and Fry, W. E. 2000. Potato late-blight management in the Toluca Valley: Forecasts and resistant cultivars. Plant Dis. 84:410-416.

We evaluated host resistance and fungicide forecasting as components of integrated management in the Toluca Valley of central Mexico. Potato cvs. Rosita and Norteña showed high levels of resistance (20 and $4 \%$ final disease severity, respectively) in the no-spray controls, whereas susceptible cv. Alpha was at $90 \%$ defoliation well before the end of the season. Disease on Alpha was well managed with a weekly spray of chlorothalonil. None of three published forecast systems was entirely appropriate for this pathosystem. SIM-CAST accurately allocated fungicide for a susceptible cultivar but needs to be adapted for the high level of resistance of Rosita and Norteña. TOM-CAST and BLITECAST did not recommend the initial fungicide application until after disease was well established in the plots. We believe that the low-temperature response of Phytophthora infestans needs to be reevaluated for the highland tropics.
\end{abstract}

Additional keywords: epidemiology, yield loss

The Highlands of central Mexico are considered to be the center of origin of the potato late-blight pathogen Phytophthora infestans (Mont.) de Bary (22). This hypothesis is based on restriction fragment length polymorphism (RFLP) fingerprinting using the RG-57 probe, isozyme analysis at the Peptidase and Glucose-6-phosphate isomerase loci, mating type frequency, and several other characters such as metalaxyl resistance, race structure, and growth morphology $(12,14,22)$. More evidence supporting this hypothesis comes from the presence of genes for resistance in native Solanum spp. All named major genes for resistance to potato late blight have been found in S. demissum Lindl. and S. stoloniferum (22). Both of these species can easily be found in rural areas of central Mexico. Further support comes from the fact that oospores are commonly produced in nature on cultivated and wild Solanum spp. (16,21; Flier, N. J. Grünwald, and W. E. Fry, unpublished results). Because

Corresponding author: N. J. Grünwald

E-mail: njg7@cornell.edu

PICTIPAPA (Programa Internacional Cooperativo del Tizón Tardío de la Papa) and the CEEM (Cornell-Eastern Europe-Mexico) Potato Late Blight Project funded this work.

Accepted for publication 19 November 1999.

Publication no. D-2000-0125-03R

(C) 2000 The American Phytopathological Society oospores were rare in the field outside of central Mexico, the biology, ecology, and epidemiology of oospores remains basically unexplored (1). All of these facts strongly support the hypothesis that central Mexico is the center of genetic diversity of this pathogen.

Most research on $P$. infestans in central Mexico has been conducted in the Toluca Valley. The Toluca Valley offers a tropical highland climate due to the latitude $\left(19^{\circ} 14^{\prime} \mathrm{N}, 99^{\circ} 34^{\prime} \mathrm{E}\right)$ and altitude of the area $(2,640 \mathrm{~m}$ above sea level). This valley is characterized by monthly average temperatures in the range of 12 to $17^{\circ} \mathrm{C}$ and a yearly rainfall of approximately 800 to 900 $\mathrm{mm}$. Potatoes (Solanum tuberosum) are grown during the summer months, which are characterized by cool (daily average temperature: 15 to $16^{\circ} \mathrm{C}$ ) and wet (average daily precipitation: 5 to $8 \mathrm{~mm} /$ day) weather $(2,23)$. In addition to foregoing the need for irrigation, growing potatoes in the rainy season helps avoid Purple Top because leafhopper vectors are adversely affected by rain. However, the long hours of prolonged leaf wetness, almost daily rains in the late afternoons, and low average temperatures make conditions ideal every day for late-blight development during the potato-growing season.

Late blight has become one of the most expensive diseases worldwide, both in terms of disease control and yield and postharvest losses $(12,13)$. This is particularly true for the Toluca Valley. Under normal circumstances, growers use 16 to 24 appli- cations of fungicides per crop with cvs. Alpha or Atlantic, both of which are susceptible to the pathogen, but comprise around $50 \%$ of the potato acreage (25). Integration of host resistance and forecasting could considerably reduce the current production costs $(10,15)$.

The Mexican national breeding program has produced several cultivars with high levels of field resistance (7). Cultivars like Norteña and Rosita express levels of field resistance that seem to be higher than those reported in American cultivars. These cultivars produce 20 to 30 tons/ha without a single fungicide application (7).

On the other hand, forecasting systems such as BLITECAST (20) and calendar spray schedules have been used with success in temperate climates to control late blight. BLITECAST (19), TOM-CAST (17), and other forecasting systems, such as SIM-CAST (11), were developed for temperate climates such as those that occur in upstate New York and Pennsylvania, where periods that are both conducive and non-conducive for epidemic development occur. It is not clear whether these forecasting systems would be of benefit in the Toluca Valley. TOM-CAST was originally developed to control early blight, Septoria leaf blight, and anthracnose rot of tomatoes (17). Both TOM-CAST and BLITECAST forecast the first spray and include subsequent spray scheduling. SIM-CAST uses a decision rule structure similar to that of BLITECAST and TOM-CAST by accumulating disease severity values, but does not forecast the occurrence of the first spray. In addition, SIM-CAST explicitly includes levels of resistance and degree of fungicide weathering in the decision rules. To the best of our knowledge, within Mexico, only TOM-CAST has been used successfully in Northern Mexico (R. FélixCastélum, personal communication).

Our objective was to initiate integrated management strategies for control of potato late blight in the Toluca Valley. The first steps were to evaluate existing forecast systems and to quantify host resistance available in the Toluca Valley. To this end, four forecasting systems for control of potato late blight and two calendar spray schedules were evaluated using potato cultivars considered to be susceptible, moderately susceptible, and resistant to late blight. 


\section{MATERIALS AND METHODS}

Cultural procedures. Field experiments were conducted at the Instituto Nacional de Investigaciones Forestales, Agrícolas y Pecuarias (INIFAP) field station in Metepec, Toluca Valley, in 1997 and 1998. Whole tubers of cv. Alpha were planted on 11 June 1997 and of cvs. Alpha, Rosita, and Norteña on 18 June 1998. Cvs. Rosita and Norteña, provided by INIFAP, emerge later and over a longer period and mature later than cv. Alpha. A private company provided Alpha seed tubers. Experimental plots were 4 by $3.7 \mathrm{~m}$ wide (4 rows/plot; 16 plants/row). Treatments were randomized in complete blocks with four replications. Plots were separated from each other by $4 \mathrm{~m}$. Yields were estimated by harvesting tubers and re-scaling yields to kilograms per hectare without adjusting for the effect that small plot sizes have on yields. Potatoes were not graded for quality.

Fertilization and non-experimental pesticide applications were applied according to standard grower practice in the region. Tubers were treated with benomyl (Benlate; $1 \mathrm{~kg}$ a.i./ha) and Captan (Captan 50 $\mathrm{PH} ; 1 \mathrm{~kg}$ a.i./ha) in the planting hole with a hand sprayer. Fertilizer was applied at time of planting $(120 \mathrm{~kg}$ of $\mathrm{N}, 180 \mathrm{~kg}$ of $\mathrm{P}, 120$ $\mathrm{kg}$ of $\mathrm{K}$, and $20 \mathrm{~kg}$ of $\mathrm{Ca}$ and $\mathrm{Mg}$ per hectare) together with the granulated insecticide terbufos (Counter FZ-15; 1.05 $\mathrm{kg}$ a.i./ha). A second fertilizer application (60 kg of $\mathrm{N})$ was applied at hilling on 17 July 1997 and on 23 July 1998. The fungicide chlorothalonil (Bravo 720) was applied at a rate of $1.15 \mathrm{~kg}$ a.i./ha with a hand sprayer. The herbicide metribuzin (Lexone) was applied at a rate of $525 \mathrm{~g}$ a.i./ha when needed. Several insecticides were applied weekly in rotation as needed (methamidophos, dimethoate, oxamyl, monocrotophon, methomyl, and endosulfan).

Fungicide spray forecasting. In 1997, five treatments were included (Table 1). These consisted of a no-spray control (0$\mathrm{S}$ ), two scheduled applications (once weekly [1-S] and twice weekly [2-S]) and two forecasting systems: a modification of BLITECAST (BCM; 19) and TOM-CAST
(TC; 17). The modifications to BLITECAST resulted from the observation during the beginning of the 1997 field season that disease severity values were not accumulating fast enough for an initial spray. To accumulate disease severity values more quickly, daily average temperatures, rather than average temperatures during hours of relative humidity above $90 \%$, were used for forecasting. In both years, fungicide applications in the standard grower practice treatments were initiated on the day when the first late blight lesions were detected in the area.

In 1998, we included three forecasting systems, the original BLITECAST (BC), the modification of BLITECAST (BCM) and SIM-CAST (SIM; 11), in combination with three potato varieties (Table 1). The first fungicide application using SIM was set to occur as soon as 40 blight units were reached. Cvs. Alpha, Rosita, and Norteña were considered to be susceptible, moderately susceptible, and moderately resistant, respectively, to late blight.

Weather data. In 1997, canopy air temperature and humidity were monitored using a hygrothermograph sheltered in a white wooden house placed within the potato canopy about $15 \mathrm{~cm}$ off the ground. Rainfall was measured using a rain gauge placed above the canopy. Data were recorded manually every morning to enable forecasting. Forecasting was started on 1 July at $50 \%$ crop emergence.

In 1998, canopy air temperature and humidity were measured with a shielded thermistor and a sulfonated polystyrene humidity transducer, respectively (207 probe, Campbell Scientific, Logan, UT). The probe was placed $0.5 \mathrm{~m}$ above soil level inside the canopy of cv. Alpha in a plot corresponding to the SIM treatment. Rainfall was measured with an automated TE525 tipping-bucket rain gage (Texas Instruments, Dallas), located in a fully automated weather station approximately $100 \mathrm{~m}$ from the plots. All sensor signals were sampled at 5-min intervals, and 60min averages were calculated to enable daily forecasting. Weather data were downloaded daily to produce forecasts. Forecasting was started on 6 July at 50\% crop emergence.

Disease estimates. Percent disease severity was assessed on a plot basis and was estimated visually as described previously (9). Assessments were made every three to five days starting on 3 July 1997 or 16 July 1998 until application of a vine killer. Scouting for disease was initiated at emergence of the crop, so that onset could be determined accurately.

Fungicide efficiency. The ratio of yield $\left(10^{3} \mathrm{~kg} \mathrm{ha}^{-1}\right)$ to fungicide applied ( $\mathrm{kg}$ a.i. $\mathrm{ha}^{-1}$ ) was calculated to reflect fungicide efficiency $\left(10^{3} \mathrm{~kg}\right.$ of tubers $/ \mathrm{kg}$ a.i. of fungicide). This ratio allows comparison only within a single cultivar, because potential yield and growing period differ among cvs. Alpha, Rosita, and Norteña.

Statistical analyses. Variables included in the data analysis were relative area under disease progress curve (RAUDPC), highest disease severity of the season $\left(y_{\max }\right)$ (both a measure of disease severity), and total tuber yield. RAUDPC in units of percent-days (possible range of 0 to $100 \%$ days) were calculated using the midpoint method (5) and dividing the AUDPC by length of the assessment period (9) to enable comparison between treatments with different assessment periods. Analyses of variance, including orthogonal contrasts (CONTRAST statement in PROC GLM), were conducted on yields, RAUDPCs, and final levels of disease severity at the end of the season $\left(y_{\max }\right)$ (SAS User's Guide: Statistics, SAS Institute, Cary, NC). Only RAUDPCs are presented, because $y_{\max }$ behaved qualitatively the same in every analysis as RAUDPC.

\section{RESULTS}

Weather. In both 1997 and 1998, most days exhibited a climate favorable to lateblight development. In both years, mean daily temperature remained around $15^{\circ} \mathrm{C}$, with a daily minimum around 5 to $10^{\circ} \mathrm{C}$ and a daily maximum temperature around 20 to $25^{\circ} \mathrm{C}$ (Fig. 1). In 1997, relative humidity remained above $90 \%$ for at least 10

Table 1. Definition of abbreviations for treatments applied to experiments conducted at the Experimental Field Station of the Mexican National Potato Program of INIFAP in the Toluca Valley in 1997 and 1998

\begin{tabular}{|c|c|c|c|c|c|}
\hline Abbreviation & Cultivar & Fungicide treatment & Year & Description & Reference for forecasting system \\
\hline $0-\mathrm{S}-\mathrm{AL}$ & Alpha & None & $1997-1998$ & Control & $\ldots$ \\
\hline $1-\mathrm{S}-\mathrm{AL}$ & Alpha & Weekly & $1997-1998$ & Weekly spray & $\ldots$ \\
\hline 2-S-AL & Alpha & Twice weekly & $1997-1998$ & Spray twice weekly & $\ldots$ \\
\hline BCM-AL & Alpha & BLITECAST mod. & 1997-1998 & Forecast & Modified from 19 \\
\hline TC-AL & Alpha & TOM-CAST & 1997 & Forecast & 17 \\
\hline SIM-AL & Alpha & Simulator & 1998 & Forecast & 11 \\
\hline $0-\mathrm{S}-\mathrm{RO}$ & Rosita & None & 1998 & Control & $\ldots$ \\
\hline $1-\mathrm{S}-\mathrm{RO}$ & Rosita & Weekly & 1998 & Weekly spray & $\ldots$ \\
\hline 2-S-RO & Rosita & Twice weekly & 1998 & Spray twice weekly & $\ldots$ \\
\hline BCM-RO & Rosita & BLITECAST mod. & 1998 & Forecast & Modified from 19 \\
\hline BC-RO & Rosita & BLITECAST & 1998 & Forecast & 19 \\
\hline SIM-RO & Rosita & Simulator & 1998 & Forecast & 11 \\
\hline $0-\mathrm{S}-\mathrm{NO}$ & Norteña & None & 1998 & Control & $\ldots$ \\
\hline $1-\mathrm{S}-\mathrm{NO}$ & Norteña & Weekly & 1998 & Weekly spray & $\ldots$ \\
\hline SIM-NO & Norteña & Twice weekly & 1998 & Forecast & 11 \\
\hline
\end{tabular}


$\mathrm{h}$ on $77 \%$ of days and rainfall was recorded on $68 \%$ of days. In 1998, rains were unusually late, which resulted in delayed planting and in a later appearance of blight. Once rains started, rainfall was recorded on $90 \%$ of days and relative humidity remained above $90 \%$ for at least $10 \mathrm{~h}$ on $88 \%$ of days.

Epidemic development. Late-blight epidemics started shortly after the rainy season started and progressed steadily (Fig. $2 \mathrm{~A}$ and $\mathrm{B}$ ). Disease onset was not accurately predicted by any of the forecasting schemes. The first late-blight lesions in the general experimental area were observed on 3 July 1997 and on 16 July 1998 within the experimental plots. BCM accumulated 18 disease severity values on 17 July 1997 (mean disease severity $\pm \mathrm{SD}=0.9 \pm 0.9 \%$ ) and, in 1998, both BCM and BC accumulated 18 severity values on 23 July (mean disease severity $\pm \mathrm{SD}=0.3 \pm 0.2 \%$ and 3.3 $\pm 3.9 \%$, respectively). The first spray with SIM was initiated on 17 July after 44 blight units had accumulated. Most initial infections in both years were on leaves on the top of the canopy, indicating a predominance of air-borne inoculum. In both seasons, some primary stem lesions at the base of the plant were present, indicating that infection from oospores could have occurred. Due to the fact that inoculation is
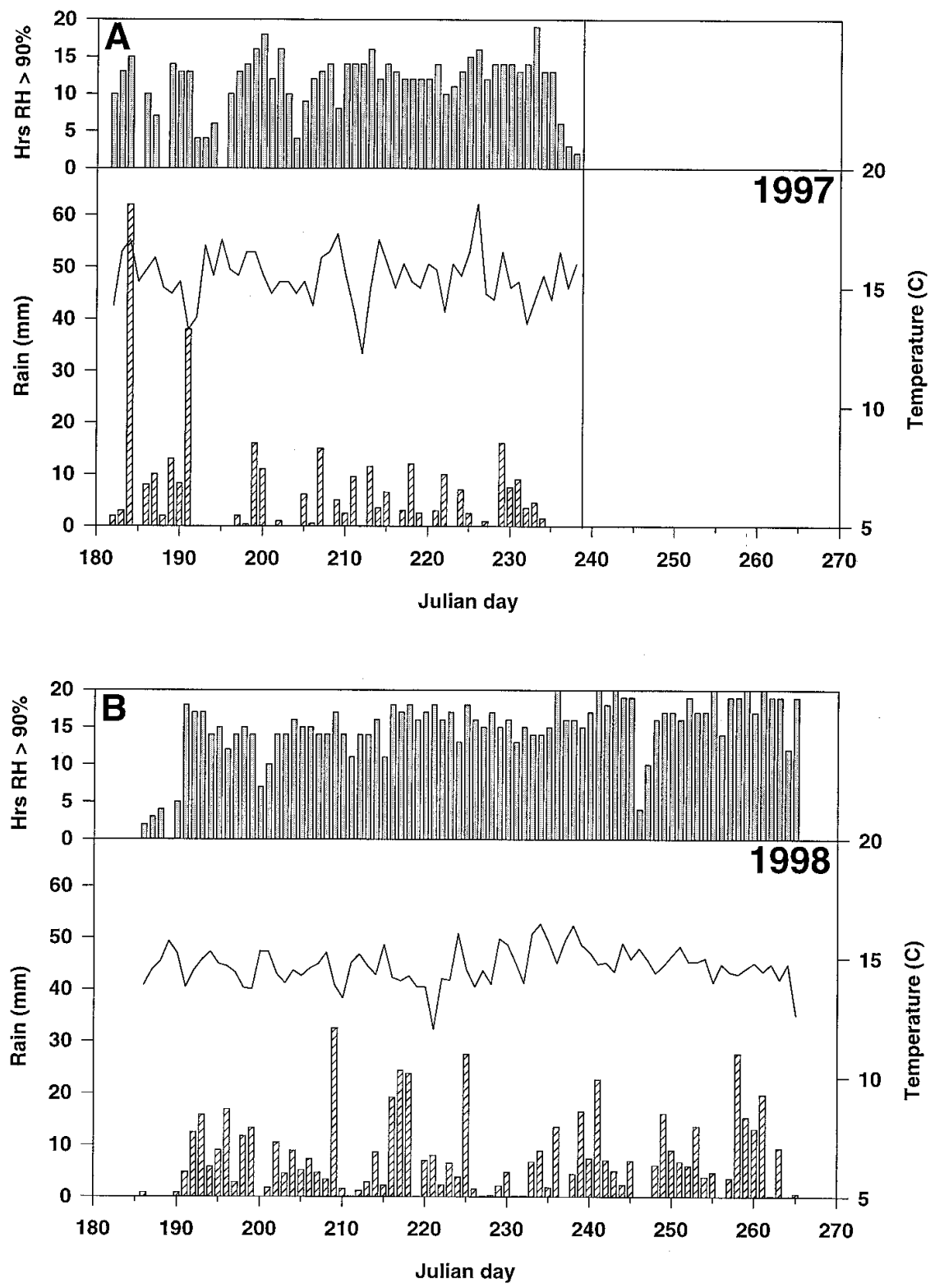

Fig. 1. Daily rainfall $(\mathrm{mm})$, average daily temperature $\left({ }^{\circ} \mathrm{C}\right)$, and number of hours during which relative humidity is above $90 \%$ (Hrs $\mathrm{RH}>90 \%$ ) during the period in which disease severity was assessed. (A) In 1997, microclimate was measured with a hygrothermograph placed within the potato canopy and a rain gage placed above the canopy. (B) In 1998, microclimate was measured using a Campbell 21-X weather station with a relative humidity and air temperature sensor placed within the canopy. Rainfall was measured with an automated tipping bucket rain gage located at a fully automated weather station $100 \mathrm{~m}$ from the plots.

natural and some plots show first lesions 2 weeks after first symptoms appear in other plots, error bars (standard deviations) are largest around the inflection point of the disease progress curves of the $0-\mathrm{S}$ cv. Alpha treatment (Figs. 2 and 3).

Cv. Alpha. Although cv. Alpha is very susceptible, the calendar spray schedules effectively suppressed late blight. Weekly applications (1-S) of chlorothalonil provided excellent suppression of late blight. This treatment had the best combination of low daily chlorothalonil dose, high fungicide efficiency, good yield, and low percentage of tuber blight (Table 2). The twice-weekly applications (2-S; standard grower practice) also resulted in good disease control but required 15 fungicide applications per season in both years (Table 2; Fig. 2). The 1-S treatment received half the applications (seven in 1997 or eight in 1998; Table 2). The forecasting treatments were less successful in suppressing late blight. In both years, most BCM spray recommendations were for a 5-day spray schedule, resulting in a total of eight and nine chlorothalonil applications in 1997 and 1998, respectively (Table 2). In 1997, TC predicted the first application on 6 August when 35 disease severity values had accumulated and mean disease severity was at $61 \%( \pm 19)$. TC was abandoned after this, because another 20 disease severity values would have to accumulate for another fungicide application to take place, which would have resulted in a total of two sprays for the season. SIM resulted in 10 fungicide applications on a 5-day schedule.

In 1997, disease severity and RAUDPC at the end of the growing season were highest in the 0-S and the TC treatments, followed by BCM and finally the 1-S and 2-S fungicide application treatments (Fig. 2A, Table 2). In 1998, disease severity and RAUDPC at the end of the season were highest in the $0-\mathrm{S}$, followed by $\mathrm{BC}$ and finally the SIM, 1-S, and 2-S fungicide application treatments (Fig. 2B, Table 2). Results from an orthogonal contrast on RAUDPCs indicate that in both field seasons, the 1-S and 2-S fungicide treatments were not significantly different from each other, and that $0-\mathrm{S}$ was significantly higher than the different fungicide applications (Tables 3 and 4). TC, BC, and BCM were significantly worse than the scheduled fungicide applications (Tables 3 and 4). SIM was significantly better than both versions of BC and not significantly different from 1-S and 2-S (Table 4).

The highest yields were obtained in the scheduled 1-S and 2-S fungicide applications followed by SIM, BC, and BCM and, finally, TC and the 0-S treatment (Tables 3 and 4). Results from an orthogonal contrast indicated that yields were significantly higher in the sprayed compared to the unsprayed treatments, the scheduled versus forecast fungicide applications, and BCM versus TC (Tables 3 and 4). In both field 
seasons, no significant difference was detected between 1-S and 2-S (Tables 3 and 4).

We found no relationship between tuber blight and foliar disease severity (either RAUDPC or $y_{\max }$; Table 2). In 1997, tuber blight was hardly detected, but in 1998, there were unseasonably wet conditions throughout the season and severe tuber blight (up to 13\%) was observed (Table 2). The SIM treatment had the highest level of tuber blight, followed by BC, 1-S, and 2-S and, finally, 0-S.

Correlations between yield and RAUDPC in $1997(r=-0.94 ; P<0.001)$ and $1998(r=-0.90 ; P<0.0001)$ were negative and highly significant. Regressions between yield $Y\left(10^{3} \mathrm{~kg} / \mathrm{ha}\right)$ and RAUDPC $X$ (proportion-days) resulted in the following relationships for cv. Alpha in 1998 and 1997, respectively: $Y=31.22-$ $50.3 X\left(R^{2}=0.81\right)$ and $Y=27.27-43.9 X$ $\left(R^{2}=0.89\right)$.

Cvs. Rosita and Norteña. Disease progressed much more slowly in these two cultivars than in $\mathrm{cv}$. Alpha. In the case of Rosita, the 2-S treatment received 18 applications, and all other treatments, ex- cluding $0-\mathrm{S}$, received 10 applications (Table 2). Norteña received 11 applications in the 1-S treatment and 8 in the SIM treatment (Table 2). Because spraying was initiated before rows were actually closed and the cultivars are later maturing, both Rosita and Norteña received more sprays than Alpha. For both cultivars, the highest fungicide efficiency was recorded in the SIM treatment (Table 2). Tuber blight was not severe, being either undetectable or staying below $1 \%$ in fungicide treatments and below $2 \%$ in the no-spray control.

Both cultivars showed a high level of resistance to late blight (Fig. 3). In the absence of any fungicide, cv. Rosita had a final disease severity of 12 to $25 \%$, while all other treatments had between 0.01 and 2\% disease (Fig. 3). Orthogonal contrasts on RAUDPCs indicated that the control treatment was significantly higher than the other five treatments $(P<0.05)$, and that no other significant differences among treatments occurred (Table 4). For cv. Norteña, there was only 2 to $8 \%$ final disease severity in the absence of fungicide (Fig. 3) and there were no significant differences among treatments (Table 4).
Yields of cvs. Rosita and Norteña were not affected by disease severity (Table 4). Even in the absence of fungicide, Rosita yielded 19 tons/ha (Table 2). Yields in unsprayed control treatments were considerably higher for the two resistant cultivars than for cv. Alpha (Table 2). For the resistant cultivars, correlations between yield and RAUDPC were negative and not significant.

\section{DISCUSSION}

Cvs. Rosita and Norteña showed a high level of resistance to $P$. infestans. Both varieties had less than $20 \%$ disease at the end of the field season without a single fungicide application. Rosita was released in 1971 (release \#PA-4/71) and Norteña in 1992 (release \#PAP-080592-011). Rosita and Norteña are currently grown on $18 \%$ and approximately 5\% (INIFAP National Potato Program, personal communication), respectively, of the national acreage. Rosita and Norteña rarely reach 50 or $20 \%$ disease severity at the end of the season, respectively (O. A. Rubio-Covarrubias, personal communication), and our results correspond well to informal reports by the
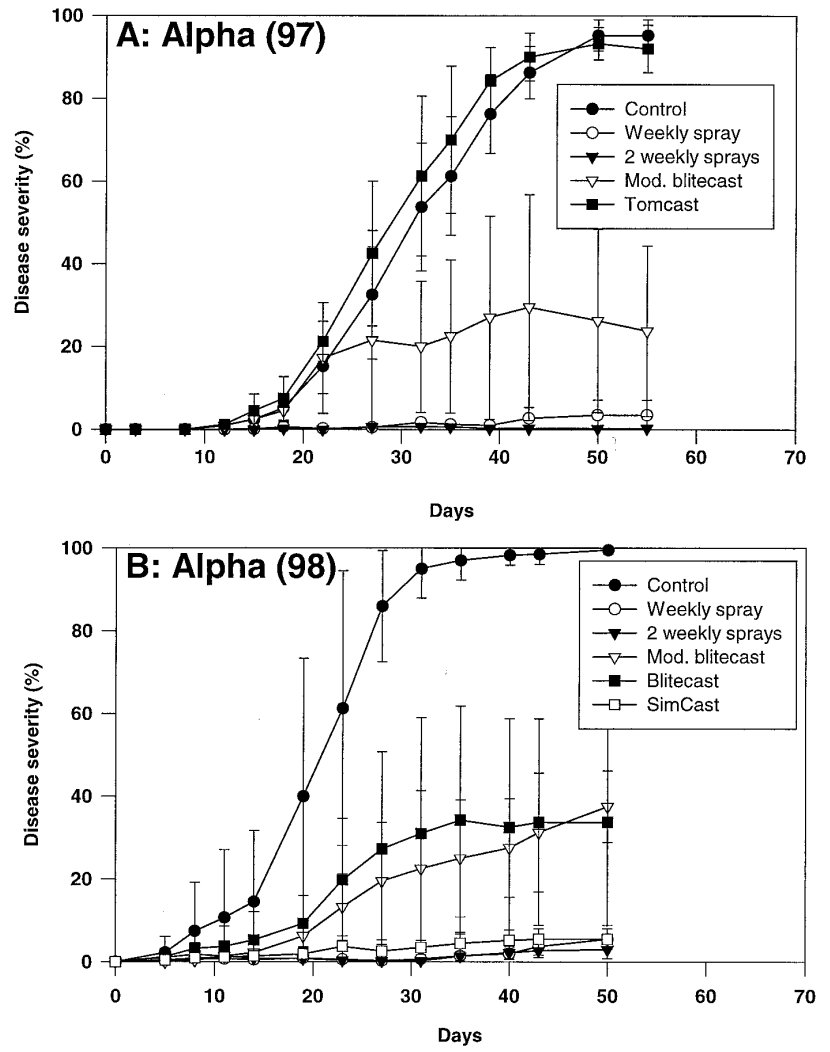

Fig. 2. Late blight progress curves on potato cv. Alpha in (A) 1997 and (B) 1998. Treatments were an unsprayed control, two scheduled fungicide applications (weekly and twice-weekly), and either two forecasting systems in 1997 (modified BLITECAST and TOM-CAST) or three forecasting systems in 1998 (BLITECAST, modified BLITECAST, and SIM-CAST). Shown are means and standard deviations from visual disease severity assessments, in four replicate plots, starting 4 July 1997 and 16 July 1998 when first symptoms were observed in the area.
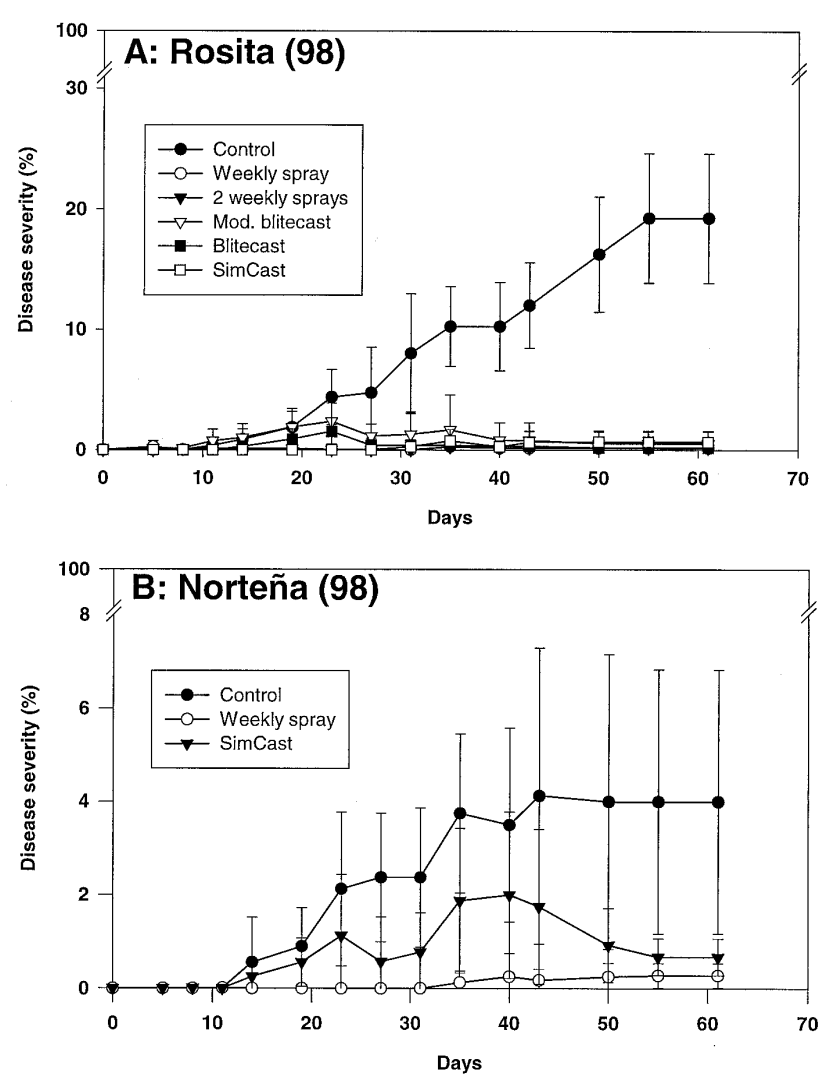

Fig. 3. Disease progress curves of potato late blight on (A) moderately susceptible cv. Rosita and (B) resistant cv. Norteña in 1998. With Rosita, treatments included an unsprayed control, two scheduled fungicide applications (weekly and twice-weekly), and three forecasting systems (BLITECAST, modified BLITECAST, and SIM-CAST). With Norteña, only three treatments were included: an unsprayed control, a weekly fungicide application, and the SIM-CAST forecasting system. Shown are means and standard deviations from visual disease severity assessments on four replicate plots starting 16 July 1998, when first symptoms were observed in the area. 
national potato program (INIFAP). Rosita has been grown commercially for 27 years and its resistance to late blight has not changed (O. A. Rubio-Covarrubias, personal communication).

Of the forecasting systems tested, SIM performed best. In all cases, use of SIM predictions resulted in excellent disease control (in terms of RAUDPC and $y_{\max }$ values) and was equal to the weekly spray treatment. With increasing level of resistance (from cv. Alpha to cvs. Rosita and Norteña), the number of fungicide applications declined, even though the growing cycle was longest for Norteña, followed by Rosita and then Alpha. The initial spray threshold was arbitrarily set to 40 accumulated blight units. This value seems optimal for use with Alpha in the Toluca Valley, but will need further validation in the future.

SIM will need to be modified for use with cvs. Rosita and Norteña. These cultivars do not need 10 or 8 applications of fungicide per season. For use with SIM,
Rosita and Norteña were considered to be moderately susceptible and moderately resistant, respectively. Moderately susceptible and moderately resistant are the highest levels of resistance taken into account by SIM (11). Varieties considered to be moderately resistant in SIM, such as cvs. NY59 (52.1 and 67\% final disease severity and RAUDPC = 13 and 18\%-days; data from 1979 and 1980, respectively), Rosa (100 and $92.5 \%$ final disease severity and RAUDPC = 49 and 23\%-days; data from two independent experiments in 1981), and Sebago $(82.7 \%$ final disease severity and RAUDPC $=18 \%$-days; data from 1981) in upstate NY experiments (11) are more susceptible than Rosita (20\% final disease severity and RAUDPC $=7.5 \%$-days) and Norteña (4\% final disease severity and RAUDPC $=2.4 \%$-days). In a 1-year trial in which cv. Alpha was grown together with cvs. Sebago, Hudson, and Superior in Toluca, Mexico, using the same isolate of P. infestans, Alpha (AUDPC 8.3) showed an intermediate level of resistance when compared with Sebago (6.3), Hudson (9.8), and Superior (11.1) based on mean AUDPC (24). Disease progress based on RAUDPC or final disease cannot be compared across locations and seasons; however, the strong difference in level of resistance of Rosita and Norteña indicates that SIM should be modified to include the resistance level of these two Mexican cultivars. Based on our results and consultation with INIFAP, Rosita and Norteña could be considered to be resistant and highly resistant, respectively.

Potato late blight on susceptible cv. Alpha was well suppressed with one to two applications of chlorothalonil per week. Fungicide applications made by SIM controlled disease well, but resulted in one more application in the season. Based on our results from two field seasons, it appears that a weekly, scheduled fungicide application is optimal. This result will have to be validated in larger field trials, due to the fact that our results are based on plots of 4 by $4 \mathrm{~m}$ and applications with hand

Table 2. Evaluation of different fungicide application treatments with three levels of host resistance

\begin{tabular}{|c|c|c|c|c|c|c|c|}
\hline Treatment $^{\mathrm{t}}$ & Year & No. applications & Chlorothalonil $^{u}$ & Fungicide efficiency & RAUDPC $^{w}$ & Yield $^{x}$ & Tuber blight $(\%)^{\mathrm{y}}$ \\
\hline \multirow[t]{2}{*}{$0-\mathrm{S}-\mathrm{AL}$} & 1997 & 0 & 0 & $\ldots$ & $40.7 \pm 4.6$ & $8.3 \pm 0.6$ & \\
\hline & 1998 & 0 & 0 & $\ldots$ & $58.8 \pm 10.8$ & $2.1 \pm 1.7$ & $1.0 \pm 1.2 \mathrm{~d}$ \\
\hline \multirow[t]{2}{*}{ 1-S-AL } & 1997 & 7 & 0.14 & 3.3 & $1.2 \pm 0.9$ & $26.7 \pm 0.6$ & $\ldots$ \\
\hline & 1998 & 8 & 0.16 & 3.6 & $1.4 \pm 0.6$ & $33.5 \pm 2.3$ & $3.4 \pm 2.2 \mathrm{bc}$ \\
\hline \multirow[t]{2}{*}{ 2-S-AL } & 1997 & 15 & 0.29 & 1.7 & $0.3 \pm 0.2$ & $28.8 \pm 5.0$ & .. \\
\hline & 1998 & 15 & 0.29 & 2.1 & $1.3 \pm 0.5$ & $35.4 \pm 3.4$ & $3.1 \pm 1.7 b c$ \\
\hline $\mathrm{TC}$ & 1997 & $2^{z}$ & 0.04 & 3.5 & $43.8 \pm 6.2$ & $8.1 \pm 0.9$ & $\ldots$ \\
\hline \multirow[t]{2}{*}{ BCM-AL } & 1997 & 8 & 0.16 & 2.2 & $15.3 \pm 13.2$ & $20.0 \pm 4.2$ & $\ldots$ \\
\hline & 1998 & 9 & 0.18 & 1.8 & $15.5 \pm 7.7$ & $18.1 \pm 7.1$ & $5.1 \pm 0.5 b$ \\
\hline BC-AL & 1998 & 9 & 0.18 & 2.1 & $19.4 \pm 15.6$ & $21.4 \pm 9.3$ & $4.4 \pm 1.8 \mathrm{bc}$ \\
\hline SIM-AL & 1998 & 10 & 0.19 & 2.3 & $3.0 \pm 1.2$ & $26.8 \pm 2.5$ & $13.1 \pm 3.1 \mathrm{a}$ \\
\hline 0-S-RO & 1998 & 0 & 0 & $\ldots$ & $6.8 \pm 2.3$ & $19.4 \pm 4.7$ & $1.0 \pm 0.9 \mathrm{~d}$ \\
\hline $1-\mathrm{S}-\mathrm{RO}$ & 1998 & 10 & 0.19 & 1.8 & $0.1 \pm 0.2$ & $20.8 \pm 4.0$ & $0.2 \pm 0.4 \mathrm{~d}$ \\
\hline 2-S-RO & 1998 & 18 & 0.34 & 1.0 & $0.1 \pm 0.1$ & $21.4 \pm 2.4$ & $0.0 \pm 0.0 \mathrm{~d}$ \\
\hline BCM-RO & 1998 & 10 & 0.19 & 1.9 & $1.1 \pm 1.1$ & $21.3 \pm 2.2$ & $0.0 \pm 0.0 \mathrm{~d}$ \\
\hline BC-RO & 1998 & 10 & 0.19 & 1.9 & $0.4 \pm 0.5$ & $21.4 \pm 6.3$ & $0.0 \pm 0.0 \mathrm{~d}$ \\
\hline SIM-RO & 1998 & 10 & 0.19 & 2.0 & $0.3 \pm 0.4$ & $23.3 \pm 2.4$ & $0.0 \pm 0.0 \mathrm{~d}$ \\
\hline $0-\mathrm{S}-\mathrm{NO}$ & 1998 & 0 & 0 & $\ldots$ & $2.2 \pm 1.3$ & $25.3 \pm 4.2$ & $0.1 \pm 0.3 \mathrm{~d}$ \\
\hline $1-\mathrm{S}-\mathrm{NO}$ & 1998 & 11 & 0.16 & 2.3 & $0.1 \pm 0.1$ & $29.1 \pm 4.4$ & $0.8 \pm 1.6 \mathrm{~d}$ \\
\hline SIM-NO & 1998 & 8 & 0.12 & 2.8 & $0.8 \pm 0.4$ & $26.1 \pm 3.4$ & $0.0 \pm 0.0 \mathrm{~d}$ \\
\hline
\end{tabular}

${ }^{\mathrm{t}} 0-\mathrm{S}=$ no treatment, $1-\mathrm{S}=$ weekly, $2-\mathrm{S}=$ twice weekly, $\mathrm{TC}=$ TOM-CAST, $\mathrm{BC}=\mathrm{BLITECAST}, \mathrm{BCM}=$ modified BLITECAST, $\mathrm{SIM}=\mathrm{SIM}-\mathrm{CAST}$, AL = cv. Alpha, RO = cv. Rosita, and $\mathrm{NO}=\mathrm{cv}$. Norteña.

u Measured at kg a.i. $\mathrm{ha}^{-1}$ day $^{-1}$.

${ }^{\mathrm{v}}$ Fungicide efficiency $\left(10^{3} \mathrm{~kg}\right.$ tubers $/ \mathrm{kg}$ a.i. fungicide $)=$ yield in $\left(10^{3} \mathrm{~kg} / \mathrm{ha}\right) /$ total amount of fungicide applied $(\mathrm{kg}$ a.i./ha) .

${ }^{\mathrm{w}}$ Relative area under the disease progress curve, mean \pm standard deviation (SD) in percent-days.

${ }^{x}$ Mean $\pm \mathrm{SD}, 10^{3} \mathrm{~kg} \mathrm{ha}^{-1}$.

y Mean \pm SD. In 1997, tuber blight was not recorded because it was observed at less than $1 \%$ and most plots had no tuber blight. Values followed by the same letter are not significantly different $(P=0.05)$ using a Fisher's protected least significant difference (LSD $=1.79 ; n=$ four replications per treatment). No transformation was applied for percentages of tubers blighted.

${ }^{\mathrm{z}} \mathrm{TC}$ : the second application was only forecast and not applied.

Table 3. Orthogonal contrasts on relative area under the disease progress curves (RAUDPC) and yield

\begin{tabular}{|c|c|c|c|c|c|c|}
\hline \multirow[b]{2}{*}{ Orthogonal contrast $^{\mathrm{z}}$} & \multicolumn{3}{|c|}{ RAUDPC $^{x}$} & \multicolumn{3}{|c|}{ Yieldy } \\
\hline & MS & $F$ value & $P>F$ & $\operatorname{MS}\left(10^{5}\right)$ & $F$ value & $P>F$ \\
\hline $0-\mathrm{S}-\mathrm{AL}$ versus other ALs & 2085.6 & 37.5 & 0.0001 & 51194.5 & 51.3 & 0.0001 \\
\hline $1-\mathrm{S} / 2-\mathrm{S}$ versus $\mathrm{BCM}-\mathrm{AL} / \mathrm{TC}-\mathrm{AL}$ & 3326.1 & 59.8 & 0.0001 & 7442.6 & 74.6 & 0.0001 \\
\hline 1-S-AL versus 2-S-AL & 1.9 & 0.03 & 0.8569 & 82.5 & 0.8 & 0.3810 \\
\hline TC-AL versus BCM-AL & 1623.6 & 29.18 & 0.0002 & 2790.7 & 28.0 & 0.0002 \\
\hline
\end{tabular}

${ }^{x}$ RAUDPC; percent-days. Maximum level of disease severity $\left(y_{\max }\right)$ behaved the same in all analyses as RAUDPC and is therefore not presented.

y Yield $10^{3} \mathrm{~kg} \mathrm{ha}^{-1}$.

${ }^{z}$ Untreated control (0-S), once (1-S), or twice-weekly (2-S) fungicide applications or fungicide applications based on modified BLITECAST (BCM) or TOM-CAST (TC) forecasts for $\mathrm{cv}$. Alpha (AL) for the 1997 experiment ( $n=$ four replications per treatment). 
sprayers. Current practice is to apply 16 to 24 applications to the cycle (25); therefore, we see potential for reduction in numbers of fungicide applications.

All initial spray advisories in BC, BCM, and TC failed; therefore, we evaluated several additional existing forecasting systems for date of initial spray forecast using the weather data from 1997 and 1998 $(3,4,27)$. Each of these additional forecasting systems failed to predict a first spray sufficiently early by a margin similar to that of $\mathrm{BC}$, ranging anywhere from 8 to 15 days after disease was first observed.

A fourth forecasting system, NEGFRY (18), had potential. NEGFRY is a forecasting system that incorporates the negative prognosis method $(26,28)$ to predict the first spray and SIM for fungicide scheduling once the first spray has been recommended. We calculated the first spray using the 150 threshold of the negative prognosis method, which would have resulted in a first application on 27 July 1998. Using a threshold of 40 accumulated blight units for SIM without use of the negative prognosis method allowed us to control disease as well as minimize numbers of spray applications, with the first spray occurring on 13 July.

Several factors might be responsible for the poor timing of the initial spray forecast. The source of primary inoculum is not known. The weather in Toluca is very cool and it rains most days in the late afternoon. Thus, most days have periods of relative humidity above $90 \%$ for at least 10 to $12 \mathrm{~h}$, but the temperature during those periods is rather low $\left(4\right.$ to $13^{\circ} \mathrm{C}$ ). Often, a heavy fog is present until about 9:00 A.M. Thus, requirements for leaf wetness are met on most days, but temperatures are too low for accumulation of disease severity values.
All forecasting models mentioned above were developed for northern, temperate climates with warmer daytime temperatures. While late blight always occurs in Toluca, and conditions during the rainy season are consistently favorable, disease seems to progress more slowly than it sometimes does in temperate climates such as upstate New York, where an epidemic on susceptible cultivars takes about 35 to 45 days (11). In both years, it took about 50 to 55 days from the beginning of the epidemic on cv. Alpha to $100 \%$ disease (Fig. 2). Average temperature during hours of high relative humidity is around $12^{\circ} \mathrm{C}$, with many periods during which the temperature falls below $7^{\circ} \mathrm{C}$. Many of the forecasting systems developed for northern temperate environments appear inaccurate for temperatures typical of this highland valley. Whereas the forecasts assume no pathogen development at temperatures below $7^{\circ} \mathrm{C} \quad(19), \quad 8^{\circ} \mathrm{C} \quad(6)$, or $10^{\circ} \mathrm{C}$ $(3,4,8,27)$, it seems clear that $P$. infestans continues to develop at these temperatures in the Toluca Valley. Such low temperatures are regularly achieved there (for example, 29 of 50 days had hourly temperatures $\leq 10^{\circ} \mathrm{C}$ and 5 of 50 days had hourly temperatures $\leq 7.2^{\circ} \mathrm{C}$ in 1998). Given that disease progress is constant, we believe that these low temperature thresholds common in north-temperate forecasting systems are inappropriate for application in the Toluca Valley. The temperature response of $P$. infestans needs to be reassessed for the Toluca Valley and other tropical highland regions.

Epidemics of late blight in the Toluca Valley seem to begin shortly after the rainy season starts. Thus, potatoes are grown when conditions are most conducive to blight. Use of cultivars with high levels of field resistance, such as Rosita and Norteña, in combination with a properly adapted fungicide forecasting system like SIM, show promise for use in the Toluca Valley. Cultivars such as Alpha are best managed with weekly or 5-day calendar spray applications.

\section{ACKNOWLEDGMENTS}

We thank PICTIPAPA for the use of their infrastructure; ICAMEX (Instituto de Investigación y Capacitación Agropecuaria, Acuícola y Forestal del Estado de México) for providing us with research equipment and laboratory facilities as well as conducting tractor work for our field plots; INIFAP for supplying research equipment, providing land, and helping with tractor work; CIMMYT for their support in the importation of equipment and logistic support; and two anonymous reviewers and $\mathrm{D}$. Shew for suggestions on the manuscript.

\section{LITERATURE CITED}

1. Andrivon, D. 1995. Biology, ecology, and epidemiology of the potato late blight pathogen Phytophthora infestans in soil. Phytopathology 85:1053-1056.

2. Anonymous. 1982. Normas climatológicas: período 1941-1970. Dirección General del Servicio Meteorológico Nacional, SARH, Ciudad de México.

3. Beaumont, A. 1947. The dependence on the weather of the dates of outbreak of potato blight epidemics. Trans. Br. Mycol. Soc. 31:45-53.

4. Bourke, P. M. A. 1955. The forecasting from weather data of potato blight and other plant diseases and pests. World Meteorol. Organ. Tech. Note 10.

5. Campbell, C. L., and Madden, L. V. 1990. Introduction to Plant Disease Epidemiology. John Wiley \& Sons, New York.

6. Duvauchelle, S. 1991. Lutte contre le mildiou de la pomme de terre en France: modèles de prévision pour les avertissements agricoles et stratégie d'utilisation des spécialités contenant des matières actives systématiques face à la resistance. EPPO Bull. 21:49-55.

7. Flores-Gutiérrez, F. X., and Cadena-Hinojosa, M. A. 1996. Evaluation of horizontal resis-

Table 4. Orthogonal contrasts for relative area under the disease progress curves (RAUDPC) and yield

\begin{tabular}{|c|c|c|c|c|c|c|}
\hline \multirow[b]{2}{*}{$\underline{\text { Orthogonal contrast }}{ }^{\mathrm{z}}$} & \multicolumn{3}{|c|}{ RAUDPC $^{\mathbf{x}}$} & \multicolumn{3}{|c|}{ Yield $^{y}$} \\
\hline & MS & $F$ value & $P>F$ & MS $\left(10^{5}\right)$ & $F$ value & $P>F$ \\
\hline \multicolumn{7}{|l|}{ Level of resistance } \\
\hline 0-S-AL versus $0-\mathrm{S}-\mathrm{RO} / 0-\mathrm{S}-\mathrm{NO}$ & $7,868.2$ & 264.9 & 0.0001 & $10,909.7$ & 53.03 & 0.0001 \\
\hline $0-\mathrm{S}-\mathrm{RO}$ versus $0-\mathrm{S}-\mathrm{NO}$ & 42.98 & 1.45 & 0.2358 & 701.4 & 3.41 & 0.0719 \\
\hline \multicolumn{7}{|l|}{ Alpha } \\
\hline $0-\mathrm{S}-\mathrm{AL}$ versus other ALs & $8,565.8$ & 287.2 & 0.0001 & $20,687.8$ & 100.56 & 0.0001 \\
\hline $\mathrm{BC}-\mathrm{AL}$ versus $\mathrm{BCM}-\mathrm{AL}$ & 31.5 & 1.06 & 0.3088 & 217.4 & 1.06 & 0.3099 \\
\hline SIM-AL versus BC-AL & 541.2 & 18.14 & 0.0001 & 587.9 & 2.86 & 0.0983 \\
\hline SIM-AL versus $1-\mathrm{S}-\mathrm{AL}$ & 4.99 & 0.17 & 0.6845 & 877.8 & 4.27 & 0.0451 \\
\hline 1-S-AL versus $2-\mathrm{S}-\mathrm{AL}$ & 0.034 & 0.0 & 0.9733 & 75.1 & 0.36 & 0.5490 \\
\hline \multicolumn{7}{|l|}{ Rosita } \\
\hline 0-S-RO versus other ROs & 138.0 & 4.656 & 0.0369 & 169.2 & 0.82 & 0.3696 \\
\hline BC-RO versus BCM-RO & 0.753 & 0.03 & 0.8743 & 0.396 & 0.00 & 0.9652 \\
\hline SIM-RO versus BC-RO & 0.023 & 0.0 & 0.9782 & 71.5 & 0.35 & 0.5587 \\
\hline SIM-RO versus $1-\mathrm{S}-\mathrm{RO}$ & 0.053 & 0.0 & 0.9667 & 122.9 & 0.59 & 0.4458 \\
\hline 1-S-RO versus $2-S-R O$ & 0.00001 & 0.0 & 0.9995 & 7.1 & 0.03 & 0.8540 \\
\hline \multicolumn{7}{|l|}{ Norteña } \\
\hline 0-S-NO versus other NOs & 7.79 & 0.26 & 0.6112 & 136.9 & 0.67 & 0.4193 \\
\hline SIM-NO versus $1-\mathrm{S}-\mathrm{NO}$ & 1.12 & 0.04 & 0.8469 & 176.3 & 0.86 & 0.3599 \\
\hline
\end{tabular}

${ }^{x}$ RAUDPC; percent-days. Maximum level of disease severity $\left(y_{\max }\right)$ behaved the same in all analyses as RAUDPC and is therefore not presented.

y Yield $10^{3} \mathrm{~kg} \mathrm{ha}^{-1}$.

${ }^{\mathrm{z}}$ Untreated control (0-S), once (1-S), or twice-weekly (2-S) fungicide applications or fungicide applications based on BLITECAST (BC), modified BLITECAST (BCM), or SIM-CAST (SIM) with cvs. Alpha (AL; susceptible), Rosita (RO; moderately susceptible), and Norteña (NO; resistant) for the 1998 experiment ( $n=$ four replications per treatment). 
tance and effects of R-genes in ten Mexican cultivars against potato late blight (Phytophthora infestans) under natural conditions in the central plateau of Mexico. Rev. Mex. Fitopatol. 102:97-102.

8. Forsund, E. 1983. Late blight forecasting in Norway 1957-1980. EPPO Bull. 13:255-258.

9. Fry, W. E. 1977. Integrated control of potato late blight-effects of polygenic resistance and techniques of timing fungicide applications. Phytopathology 67:415-420.

10. Fry, W. E. 1980. Integration of host resistance and pesticides to manage disease. Prot. Ecol. 2:259-264.

11. Fry, W. E., Apple, A. E., and Bruhn, J. A. 1983. Evaluation of potato blight forecasts modified to incorporate host resistance and fungicide weathering. Phytopathology 73:1054-1059.

12. Fry, W. E., and Goodwin, S. B. 1997. Reemergence of potato and tomato late blight in the United States. Plant Dis. 81:1349-1357.

13. Fry, W. E., and Goodwin, S. B. 1997. Resurgence of the Irish potato famine fungus. BioScience 47:363-371

14. Fry, W. E., Goodwin, S. B., Dyer, A. T., Matuszak, J. M., Drenth, A., Tooley, P. W., Sujkowski, L. S., Koh, Y. J., Cohen, B. A., Spielman, L. J., Deahl, K. L., Inglis, D. A., and Sandlan, K. P. 1993. Historical and recent migrations of Phytophthora infestans: chronology, pathways, and implications. Plant Dis. 77:653-661
15. Fry, W. E., and Shtienberg, D. 1990. Integration of host resistance and fungicide to manage potato diseases. Can. J. Plant Pathol. 12:111-116.

16. Gallegly, M. E., and Galindo, J. 1958. Mating types and oospores of Phytophthora infestans in nature in Mexico. Phytopathology 48:274277

17. Gleason, M. L., MacNab, A. A., Pitblado, R. E., Ricker, M. D., East, D. A., and Latin, R. X. 1995. Disease-warning systems for processing tomatoes in eastern North America: Are we there yet? Plant Dis. 79:113-121.

18. Hansen, J. G., Andersson, B., and Hermansen, A. 1995. NEGFRY - A system for scheduling chemical control of late blight in potato. Pages 201-208 in: Phytophthora infestan 150. L. J. Dowley, E. Bannon, L. R. Cooke, T Keane, and E. O. O'Sullivan, eds. Boole Press, Ltd., Dublin, Ireland.

19. Krause, R. A., Massie, L. B., and Hyre, R. A. 1975. BLITECAST: A computerized forecast of potato late blight. Plant Dis. Rep. 59:95-98.

20. MacKenzie, D. R. 1981. Scheduling fungicide applications for potato late blight with BLITECAST. Plant Dis. 65:394-399.

21. Niederhauser, J. S. 1956. The blight, the blighter, and the blighted. N. Y. Acad. Sci. 19:55-63.

22. Niederhauser, J. S. 1991. Phytophthora infestans: The Mexican connection. Pages 2445 in: Phytophthora. J. A. Lucas, R. C. Shattock, D. S. Shaw, and L. R. Cooke, eds.
Cambridge University Press, Cambridge.

23. Ortiz-Trejo, C. 1992. Evaluación de un modelo de simulación para la estimación de endimientos de maíz (Zea mays L.) en valles altos. M.Sc. Thesis. Colegio de postgraduados, Montecillo, Mexico.

24. Parker, J. M., Thurston, H. D., Villarreal Gonzalez, M. J., and Fry, W. E. 1992. Stability of disease expression in the potato late blight pathosystem: a preliminary field study. Am. Potato J. 69:635-644.

25. Rubio-Covarrubias, O. A., and Flores-Gutiérrez, F. X. 1997. Programa nacional de investigación en el cultivo de la papa. Instituto Nacional de Investigaciones Forestales, Agrícolas y Pecuarias (INIFAP), Mexico City.

26. Schrödter, H., and Ullrich, J. 1967. Eine mathematisch-statistische Lösung des Problems der Prognose von Epidemien mit Hilfe meteorologischer Parameter, dargestellt am Beispiel der Kartoffelfäule (Phytophthora infestans). Agric. Meteorol. 4:119-135.

27. Smith, L. P. 1956. Potato blight forecasting by 90 percent humidity criteria. Plant Pathol 5:83-87.

28. Ullrich, J., and Schrödter, H. 1966. Das Problem der Vorhersage des Auftretens de Kartoffelkrautfäule (Phytophthora infestans) und die Möglichkeit seiner Lösung durch eine "Negativprognose". Nachrichtenbl. Dtsch. Pflanzenschutzdienstes (Braunschweig) 18:33 40 